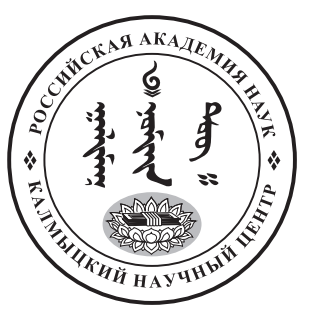

Published in the Russian Federation

Oriental Studies (Previous Name: Bulletin of the Kalmyk Institute

for Humanities of the Russian Academy of Sciences)

Has been issued as a journal since 2008

ISSN: 2619-0990; E-ISSN: 2619-1008

Vol. 14, Is. 3, pp. 428-435, 2021

Journal homepage: https://kigiran.elpub.ru

УДК / UDC 94 (517)

DOI: $10.22162 / 2619-0990-2021-55-3-428-435$

\title{
«Япония все ближе и ближе пробивается к границам Монголии... Как думаете отстаивать свою независимость?» (О беседе Сталина с П. Гэндэном 24 ноября 1934 г.)
}

\section{Лариса Будаевна Жабаева ${ }^{1}$}

${ }^{1}$ Восточно-Сибирский государственный университет технологий и управления (стр. 1, д. 40 В, ул. Ключевская, 670013 Улан-Удэ, Российская Федерация) доктор исторических наук, профессор iD 0000-0002-1486-5959. E-mail: vsgtuhistory@mail.ru

(C) КалмНЦ РАН, 2021

(C) Жабаева Л. Б., 2021

Аннотация. Введение. В начале 1930-х гг. происходит активизация двусторонних отношений между Россией и Монголией, проводятся регулярные встречи, доверительные беседы руководителей СССР и МНР. Высшее советское руководство стало более тщательно, детально заниматься монгольскими делами, внимание к которым во многом было обусловлено резким обострением международной обстановки на Дальнем Востоке, связанным с началом агрессивных действий империалистической Японии, которая громко заявила о своих планах на азиатском континенте. Руководство СССР стремится обеспечить защиту своих интересов в регионе. Целью статьи является определение значимости советско-монгольской встречи на высшем уровне 24 ноября 1934 г. Материаль и методы. Автор опирается на сборник документов российско-монгольского военного сотрудничества, где опубликованы записи бесед высшего руководства двух стран о военном сотрудничестве. Результатыл. В ходе доверительной беседы И. В. Сталина и узкого круга высшего советского руководства с монгольской делегацией во главе с премьер-министром П. Гэндэном главным вопросом стало обсуждение актуальных проблем отстаивания Монголией своей независимости в случае нападения со стороны Японии: что «будете делать, если Вам будет плохо» (И. В. Сталин). Материалы встречи позволяют понять роль внешней политики СССР по отношению к Монголии, рассмотреть ход обсуждения принципиальных проблем, которые интересовали обе стороны, влияние, оказанное Кремлем на выработку политики монгольского правительства в отношении путей защиты независимости МНР. И. В. Сталин акцентирует внимание на необходимости заключения пакта о взаимопомощи. П. Гэндэн дал согласие на переговоры и готовность договариваться практически. Монгольское руководство отчетливо осознает, что СССР является единственным союзником МНР на Дальнем Востоке. Bblводыl. Встреча на высшем уровне 24 ноября 1934 г. стала важной вехой в истории развития двусторонних отношений между СССР и МНР. Переговоры имели ключевое значение для дальнейшего 
развития военного сотрудничества. Подписанный в 1936 г. пакт о взаимопомощи обеспечил присутствие советских вооруженных сил на территории Монголии и служил гарантией ее безопасности.

Ключевые слова: обострение, международная обстановка, агрессия Японии, СССР, Сталин, Монголия, отстаивание независимости, пакт о взаимопомощи

Для цитирования: Жабаева Л. Б. «Япония все ближе и ближе пробивается к границам Монголии... Как думаете отстаивать свою независимость?» (О беседе Сталина с П. Гэндэном 24 ноября 1934 г.) // Oriental Studies. 2021. T. 14. № 3. C. 428-435. DOI: 10.22162/2619-09902021-55-3-428-435

\title{
«Japan is encroaching on the borders of Mongolia ... How do you think to uphold your independence?»: I. V. Stalin Talking to P. Genden on November 24, 1934
}

\section{Larisa B. Zhabaeva ${ }^{1}$}

${ }^{1}$ East Siberia State University of Technology and Management (40B/1, Klyuchevskaya St., 670013 Ulan-Ude, Russian Federation)

Dr. Sc. (History), Professor

iD 0000-0002-1486-5959. E-mail: vsgtuhistory@mail.ru

\author{
(C) KalmSC RAS, 2021 \\ (C) Zhabaeva L. B., 2021
}

\begin{abstract}
Introduction. The early 1930s saw a more active Russian-Mongolian interaction, including regular meetings and confidential conversations between the leaders of the USSR and the Mongolian People's Republic. I. V. Stalin and the others of the top Soviet leadership started to pay more attention to the situation in Mongolia. This was largely justified by the sharp aggravation of the international situation in the Far East, with aggressive acts of imperialist Japan in the region and its further plans on the Asian continent, of which they made no secret. Under the circumstances, the USSR leaders sought to ensure the protection of its interests in the region. This article aims at examining and interpreting the significance of the Soviet-Mongolian summit that took place on November 24, 1934. Data and research methods. The author draws on a collection of documents on Russian-Mongolian military cooperation, which contains recordings of conversations between the top leadership of the two countries on military cooperation. Results. The main issue of the confidential conversation between Stalin, with the closest to him in the top Soviet leadership, and the Mongolian delegation, with Prime Minister Peljidiin Genden at the head, was a discussion of the urgent problem of how Mongolia would uphold its independence in the event of an attack from Japan: "what will you do if your situation worsens"? (Stalin) The materials of the meeting allow to understand the role of the USSR's foreign policy in relation to Mongolia; to consider the course of discussions around the principal issues that interested both sides; and to shed light on the influence exerted by the Kremlin on the policy of the Mongolian government in terms of the ways of protecting the independence of the MPR. Stalin stressed the need to conclude a pact of mutual assistance; Genden agreed to start negotiations and was ready to elaborate practical steps. The Mongolian leadership was fully aware that the USSR was the only ally of the Mongolian People's Republic in the Far East. Conclusions. The summit meeting of November 24, 1934 became an important milestone in the history of bilateral relations between the USSR and the MPR. The negotiations proved to be of key importance for promoting their further military cooperation. The pact of mutual assistance signed in 1936 provided for the presence of the Soviet armed forces in Mongolia and served as a guarantee of the country's security.
\end{abstract}

Keywords: escalation, international situation, aggression by Japan, the USSR, Stalin, Mongolia, defense of independence, the pact of mutual assistance

For citation: Zhabaeva L. B. «Japan is encroaching on the borders of Mongolia ... How do you think to uphold your independence?»: I. V. Stalin Talking to P. Genden on November 24, 1934). Oriental Studies. 2021. Vol. 14 (3): 428-435. (In Russ.). DOI: 10.22162/2619-0990-2021-55-3-428-435 


\section{Введение}

В начале 1930-х гг. высшее советское руководство стало гораздо активнее заниматься монгольскими делами, внимание к которым стало более пристальным. Во многом это было обусловлено резким обострением международной обстановки на Дальнем Востоке, связанным с началом агрессивных действий империалистической Японии, которая громко заявила о своих далеко идущих планах на азиатском континенте, захватив с начала 1930-х гг. территорию Северного Китая, Внутреннюю Монголию и Маньчжурию, в результате чего было образовано марионеточное государство Маньчжоу-Го.

В 1931 г. в коминтерновской печати был опубликован меморандум генерала Танака от 25 июля 1927 г., содержащий подробную программу военно-политической экспансии Японии в Азии и, в частности, в отношении Монгольской Народной Республики (далее - МНР) [История Монголии 2007: 134]. Японские ученые Ф. Хироши и К. Танака утверждают, что ни сам документ, ни его копия не обнаружены [Лузянин, Грайворонский 2010: 158]. Возникает прямая угроза со стороны Японии, сильного в военном плане, экономически развитого противника не только для Монголии, но и непосредственно для советского Дальнего Востока.

Целью статьи является определение значимости советско-монгольской встречи на высшем уровне, произошедшей 24 ноября 1934 г.

Всемерная поддержка суверенитета Монголии

Внутренняя обстановка в Монголии в начале 1930-х гг. была сложной. В 1929 1931 гг. у крупных феодалов были изъяты скот и имущество, введена прогрессивная шкала налоговых выплат, предпринимались попытки закрытия буддийских монастырей, что привело к нарастанию недовольства, которое вылилось в 1932 г. в Хубсугульское восстание, направленное против политики партии и государства, за реставрацию теократической монархии в стране. По этому поводу И. В. Сталин в письме из Сочи от 4 июня 1932 г., адресованному Л. М. Кага- новичу, члену Политбюро ЦК ВКП (б), его заместителю по партии, а также членам Политбюро, пишет: «Мой ответ о Монголии, должно быть, уже получили. Самое бы лучшее - обойтись без ввода войск. Нельзя смешивать Монголию с Казахстаном или Бурятией» [Сталин и Каганович 2001: 136]. Он подчеркивает, что главное - надо заставить монгольское правительство в корне изменить политический курс. Надо оттеснить (временно) «леваков» и выдвинуть вместо них на места министров и руководителей Центрального комитета Монголии людей, способных проводить новый курс, т. е. политику советского государства [Сталин и Каганович 2001: 136]. И. В. Сталин пишет, что обновленное монгольское правительство должно всенародно объявить, что в области внутренней политики (хозяйство, религия и т. п.) допущены ошибки и что эти ошибки будут немедля исправлены. Правительству следует объявить, что главари повстанцев являются агентами китайских и, особенно, японских империалистов, стремившихся лишить Монголию свободы и независимости [Сталин и Каганович 2001: 136]. В конце письмо приписка о срочной необходимости организации отъезда Элиавы ${ }^{1}$ в Монголию [Сталин и Каганович 2001: 137].

Когда правительственная комиссия МНР выехала в район с целью изучения характера и причин восстания, цирики ${ }^{2}$ на полковом собрании задавали и такие вопросы: «Зачем понадобилась Маньчжурия для Японии, и как Япония Маньчжурию забрала - завоевала или нет?», «Какой национальности японцы - русской или китайской» [Монголия в документах 2019: 346].

Монгольское правительство направляло часть конфискованного у феодалов имущества на нужды армии. Так, на закрытом заседании правительства МНР от 27 февраля 1932 г. был заслушан доклад председателя Реввоенсовета Монгольской народной Крас-

1 Элиава Шалва Зурабович (1883-1937) член Монгольской комиссии Политбюро, заместителя наркома внешней торговли СССР с 1931 г.

${ }^{2}$ Цирик — военнослужащий (рядовой) монгольской армии. 
ной армии Демита об укреплении Красной армии и военном бюджете на 1932 г. [РГАСПИ. Ф. 495. Оп. 152. Д. 140. Л. 2]. В принятом постановлении военный бюджет был увеличен с 6 млн тугриков до 10900 тыс., из которых 3 млн были за счет конфискованного у феодалов имущества [РГАСПИ. Ф. 495. Оп. 152. Д. 140. Л. 2].

Руководство СССР стало проявлять особую заинтересованность в отношениях с Монголией. Главный фактор, определявший советскую позицию, - крайне сложная международная обстановка на Дальнем Востоке (агрессия Японии, положение в Китае), заинтересованность Советского Союза иметь на Дальнем Востоке надежного союзника с теми же целями и идеалами [Рощин 2005: 61].

Отметим, что если раньше решение многих монгольских вопросов проходило через Исполнительный комитет Коммунистического интернационала, то теперь непосредственно через ЦК ВКП(б) и СНК СССР Причины тому понятны - позиция Советского Союза к тому времени окончательно определилась: всемерная поддержка статус-кво Монголии как независимого суверенного государства, всяческое содействие успешному проведению исторического эксперимента по некапиталистическому развитию отсталой страны [Рощин 1999: 277].

В 1934 г. состоялся визит монгольской правительственной делегации во главе с премьер-министром П. Гэндэном ${ }^{3}$, связанный с заключением советско-монгольского джентльменского соглашения о взаимной помощи, и, естественно, главным образом на встрече было обсуждение вопросов необходимости подписания пакта о взаимопомощи, военного сотрудничества, укрепления обороноспособности Монголии.

И. В. Сталин к тому времени уже неоднократно встречался с П. Гэндэном, авторитетным, влиятельным политиком, их встречи на высшем уровне состоялись в декабре 1932 г., затем в декабре 1933 г., а также доверительные беседы состоялись в ноябре 1934 г., кроме того, произойдет и еще одна встреча в декабре 1935 г. Тогда, в 1934 г., И. В. Сталин принимал делегацию трижды - 15, 24 и 27 ноября [Рощин 2008: 106].

${ }^{3}$ Гэндэн П. (другой вариант передачи имени в архивных документах - Гендун) - премьер-министр МНР в 1932-1936 гг.
«Мы поднимаем тост за тех монголов, которые умеют сопротивляться, которые будут бороться» (И. В. Сталин)

Вечером 24 ноября в здании полпредства состоялся обед. С советской стороны в нем принимали участие И. В. Сталин, В. М. Молотов, К. Е. Ворошилов, А. И. Микоян и другие советские руководители. С монгольской стороны список приглашенных на обед включал 20 человек, среди которых премьер-министр П. Гэндэн, министр скотоводства и земледелия Х. Чойбалсан, министр торговли и промышленности Р. Мэнд, заместитель главкома монгольской армии О. Дашчирав и другие высокопоставленные лица. Присутствовали жены: Дашидондок (супруга полпреда Дарижапа), Денсема (супруга Самбу, второго заместителя главкома монгольской армии), Напчи (супруга Демида, военного министра), Ичинхорло (супруга Идамсуруна, зам. министра юстиции). Переводчиком с монгольской стороны был Ильин, секретарь Гэндэна. Обед проходил в дружественной и теплой атмосфере. И. В. Сталин смеялся, шутил, интересовался монгольской музыкой, пением, хвалил артистов и артисток, спросил каждого из них, сколько получает жалованья. Когда они ответили, что $70,80,100,120,160$ тугриков, говорил что мало, что они должны получать не меньше 300 руб.

Во время обеда был продолжен обмен мнениями о необходимости защиты независимости Монголии, данная тема была основной во время обеда. П. Гэндэн произнес речь в честь И. В. Сталина и других товарищей [Российско-монгольское военное сотрудничество 2008: 294]. И. В. Сталин, поднимая тост за свободную и независимую Монголию, говорил о том, что «поднимать тост, говорить, пить и есть легко. И у вас, у монголов есть такие, которые не прочь выпить и поесть за троих, и у нас в деревне найдутся такие, которые смогут выпить и поесть за троих. Это значит, что и вы, и мы - богаты. Пить и есть легко, но независимость отстаивать труднее» [Российско-монгольское военное сотрудничество 2008: 294-295].

Обращаясь к присутствующим товарищам монголам, среди которых были политики, хозяйственники, артисты, артистки, военные, И. В. Сталин говорит о том, что ходят слухи, что Япония, захватив Чахар, 
намерена напасть на Внешнюю Монголию и что потребуется отстаивать свою независимость, и отстаивать ее трудно. Он говорит о том, что «одно для меня ясно, что если вы будете спать, то Япония слопает вас. Князья Внутренней Монголии сопротивляются Японии, но это сопротивление слабое. Сопротивление князей слабое, такое сопротивление не даст пользы. Мы поднимаем тост за тех монголов, которые умеют сопротивляться, которые будут бороться» [Российско-монгольское военное сотрудничество 2008: 295].

П. Гэндэн кричит «ура». И. В. Сталин говорит, что кричать «ура» легко. «Нужно на деле отстаивать независимость Монголии, а это труднее, чем поднимать тост и разговаривать. Итак, поднимаю бокал за свободную, независимую Монголию» [Российско-монгольское военное сотрудничество 2008: 295].

Далее премьер-министр Монголии П. Гэндэн поднимал тосты за здоровье тов. В. М. Молотова, К. Е. Ворошилова, А. С. Бубнова, Г. Н. Каминского, Р. Я. Сокольникова (как инициатора предложения ликвидировать долги Монголии Советскому Союзу в размере 100 млн. руб.) и М. 3. Элиавы (как соплеменника и основателя нового курса).

После обеда делегация посетила Кремль, где был показан фильм «Чапаев». И. В. Сталин подчеркнул связь этой картины с проблемами независимости Монголии, с тем, что монголы должны двигаться дальше, поскольку существует угроза потерпеть поражение в борьбе с таким сильным врагом, как Япония.

\section{Беседа Сталина и П. Гэндэна}

После просмотра картины завязалась оживленная беседа между И. В. Сталиным, К. Е. Ворошиловым и В. М. Молотовым, с одной стороны, и П. Гэндэном - с другой. Приведем выдержки беседы.

Тов. Сталин: Япония все ближе и ближе пробивается к границам Монголии. Она не остановится на Чахаре, Долоноре, она не хочет ограничиться захватом Внутренней Монголии, а будет пытаться захватить и Внешнюю Монголию. Как думаете отстаивать свою независимость? Что будете делать, если Вам будет плохо?

Гендун: Для нас существует два пути: либо не сопротивляться, сдаться и стать колонией Японии, либо всеми силами бороться и отстаивать свою независимость.
Тов. Сталин: Сколько у Вас войска?

Гендун: 10-11 mысc. человек.

Тов. Сталин: Очень мало. Это составит не больще одной дивизии. Сколько имеете самолетов?

Гендун: Кажется, около 10 самолетов. Тов. Шеко, Даши-Чариб, идите сюда (подходит Шеко и Даши-Чариб). Сколько самолетов?

Тов. Шеко: 33 самолета.

Тов. Сталин: Мало. Ведь ваши войска составляют не больше одной дивизии. Япониам достаточно послать одну кавалерийскую дивизию при поддержке мотомеханизированных частей и самолетов, и она захватит Улан-Батор. Вдобавок Ваши войска еще не испытали войны. Половина Ваших войск может сдаться япониам добровольно. Сколько процентов составят такие перебежчики?

Гендун: Командный состав очищен от таких элементов, и измены не будет. Все зависит от того, как правильно разъяснить иирикам новый курс.

[Тов.] Даши-Чариб: Это составит незначительный прочент.

Тов. Шеко: И в командном составе найдутся такие, которые сдадутся добровольHo.

Гендун: Главное, как будет вести себя командный состав.

Тов. Сталин: К сожалению, я не дипломат. Я говорю с Вами, как революиионер. Что будете делать, когда Вам будет плохо? Ведь военные люди привыкли брать всегда худшее и из этого исходить при составлении плана. Иначе думать потом будет поздно.

Гендун: Из газетных сообщений и из всего положения я прихожу к $\mathrm{m}$ [аким] выводам: 1) соотношение сил между СССР и Японией таково, что не СССР боится Японии и оттягивает войну, а Япония боится СССР и всячески оттягивает войну. СССР гораздо сильнее, чем Япония, СССР - paстушая страна, и его мошь признана во всем мире. Япония приходит в упадок, становится все слабее и слабее (Тов. Сталин: «Неправильно, я возьму слово»), 2) В случае войны Японии с СССР в тылу Японии будет восстание (т. Сталин: «Безоружными не выступают, требуется оружие»), Япония еще не закрепилась в Маньчжурии, так как там усиливается партизанское движение, но все 
это не означает, что Япония не будет нападать на нас. 3) Протяженность наших границ настолько велика, что в случае нападения Японии мы не сможем поставить заслон от Барги до Синьизяна, ибо людей не хватит. Потребуется помощь СССР.

Тов. Сталин: Какая помощзь?

Гендун: Техническая помощь. Мы будем драться всеми силами, а там будет видно.

Тов. Сталин: Неправильно, что Япония только приходит в упадок и гниет, что она слаба. Она, конечно, слабее СССР. СССР сильно окреп за эти два года, пока Япония пережевывала Маньчжурию. СССР готов к войне и не боится Японии. Военно-техническая мощьь СССР выросла во много раз. У нас имеются бомбовозы, которые без посадки пролетают две тьсячи километров. Кроме техники, наши войска будут драться беззаветно. В случае войны нам нетрудно будет достать до Токио, быть в Харбине, Мукдене. Если начнется война, мы не остановимся, будем крушить и крушить. Большевики не останавливаются и, если они возьмутся, то дело доводят до конца. Но дело сейчас не в этом. В помощчи, конечно, мы нуждаемся, но не так, как Выл. Нам вашей помошчи особенно не требуется. А вот что будете делать, когда вам будет плохо?

Гендун: Замчищзаться всеми силами, пользуясь помощьью СССР.

Тов. Сталин: Какой помощзью?

Гендун: В первую очередь технической, а если понадобится, то и людьми (войскамu).

Тов. Сталин: На каком основании? Вашу независимость мы (большевики) понимаем в полном смысле. На вашей территории нет ни одного нашего красноармейиза. Инструкторов даем по Вашему желанию. Если они не нужны вам, мы сразу отзовем их. Если берем скот, то платим за него и будем платить. Нам ваших богатств не нужно, своих много. У нас немало ещче неосвоенных земель и в чужих территориях не нуждаемся. На каком основании мы должнь вводить на вашу территорию наши войска? Когда идет война между двумя странами, то всегда возникает вопрос - кто помогает и на каком основании.

Гендун: СССР помогал войсками в первый период револющии и сейчас также будет помогать.
Тов. Сталин: Меня нечего агитировать. Я не цииик, которого вы можете агитировать. Я ставлю вопрос прямо. Я по своему положению не являюсь дипломатом. Если хотите дипломатничать, то прошу извинения, что я так прямо ставлю вопрос. Монголия является независимой страной в полном смысле этого слова. На каком основании СССР должен помогать, и что будете делать, когда будет плохо? Что будете делать, когда вас прижмут к стенке?

Гендун: СССР призван помогать, и он будет помогать так же, как и раньше. Mы не скрываем, что пользуемся помощью СССР. Все знают, что Монголия опирается на СССР.

Тов. Ворошилов: Проводить аналогию между 1920-[19]21 г2. и настояшим периодом нельзя. Тогда и ваше, и наше государство еше не являлись оформившимися государствами. Сейчас СССР имеет дипломатические отношения со всеми крупными державами и является членом Лиги Наџий.

Тов. Сталин: Нужно говорить прощуе, а не по-интеллигентски, а то не пойму. У нас могут быть две позиции - держаться нейтралитета, сказать, что пусть Монголия и Япония воюют, а нас не касается; или сказать: Монголия - наш друг и союзник, не смей трогать ее. У вас тоже могут быть позиции: сохранять нейтралитет или же сказать, что СССР - наш друг и союзник.

Сохранять нейтралитет или быть на стороне Японии - это ваша добрая воля. Хотите быть с Японией - пожалуйста. Хотите быть с нами - тоже пожалуйста. Часть монгол того мнения, что нужно придерживаться нейтралитета, что если придержсиваться такой позиции, то, мол, Япония не будет трогать Монголию; что Монголия будет иметь возможность свободно развивать свое скотоводство. Отсюда вытекает такое настроение, что военную технику и советских людей нужно побольше возвращать обратно в СССР и т.д. Эту позицию я считаю неверной. Существует поговорка, что волк грозил ягненку съесть его за то, что тот мутит воду, стоя ниже по течению, чем волк. Эту угрозу волк и осуществил - съел ягненка. Точно так же и здесь. Япония все равно постарается слопать Монголию. С кем хотите вы быть - это ваше дело. С Японией 
или с нами. Если хотите с нами и желаете помощи, то пожалуйста.

Гендун: Мы будем с Вами и хотим помощи.

Тов. Сталин: Существует в международных отношениях так наз[вываемый] пакт взаимопомощи, согласно которого ${ }^{4}$ государства, заключившие этот пакт, в случае нападения со стороны, помогают друг другу. Такой пакт может существовать между СССР и Францией. Если Германия нападет на Франиию, то СССР помогает Франиии, и, наоборот, если Германия нападет на СССР, то Франиия помогает СССР. Если хотите помощи, то нужно договориться конкретно, а то будет поздно.

Гендун: Я сейчас только понимаю, хотя об этом я и думал, и ставил этот вопрос перед т. Ворочиловым в 1929 г., но потом его не ставил. Нам нужна помощь, и я готов договариваться конкретно.

Тов. Сталин: Так просто помогать нельзя, нужно конкретно договариваться, какую помощь оказывать. Этот вопрос очень серьезный. Одно дело - вопросы хозяйственные, другое дело, когда речь идет о политических, военных вопросах. Ваши долги по займам и по торговле мы можем просто простить или свести до копейки, поскольку мы сильнее и богаче вас. А тут вопрос более серьезный.

Гендун: Это я не учел. Я согласен договориться с Вами практически.

Т. т. Сталин и Молотов: $M$ мы поговорим о пакте взаимопомощи.

T. т. Сталин, Молотов и Ворочилов договариваются с Гендуном собраться и поговорить на эту тему 27 ноября [РГАСПИ. Ф. 558. Оп. 11. Д. 351. Л. 68-73].

\section{Заключение}

В условиях резкого обострения международной обстановки на Дальнем Востоке, вызванного агрессивными действиями империалистической Японии, экономически развитого государства, мощного в военном отношении, стремившегося к обширным территориальным завоеваниям на азиатском континенте, происходит активное укрепление двусторонних отношений между СССР и МНР. Уже в первой половине 1930-х гг. происходит ряд встреч на высшем уровне в Кремле, которые определили дальнейшее

\footnotetext{
${ }^{4}$ Так в документе. - Л. Ж
}

развитие сотрудничества, направленного на реализацию твердого и последовательного курса по развитию вооруженных сил Монголии, ее обороноспособности. Состоявшиеся встречи были весьма знаменательными. Так, в доверительной беседе лицом к лицу 24 ноября 1934 г. И. В. Сталин обсудил с П. Гэндэном актуальные проблемы защиты страны в случае нападения Японии, которая все ближе и ближе приближалась к ее границам. Основополагающая позиция внешнего курса Советского Союза в отношении Монголии сводилась не только к всемерной поддержке ее как независимого суверенного государства, но и защите своих национально-государственных интересов и безопасности.

На этой встрече И. В. Сталин также говорил о необходимости заключения пакта о взаимопомощи, на что П. Гэндэн дал согласие. Встреча на высшем уровне в ноябре 1934 г. стала важной вехой в истории развития двусторонних отношений между СССР и МНР. С этого периода между обеими странами существовало устное («джентльменское») соглашение, в соответствии с которым стороны обязались оказывать поддержку друг другу в деле предотвращения угрозы военного нападения или в случае нападения со стороны третьих стран. Переговоры имели ключевое значение для дальнейшего развития военного сотрудничества. Подписанный 12 марта 1936 г. Протокол о взаимной помощи между СССР и МНР был этапным событием, соглашением, имеющим важнейшее значение в деле развития стратегического взаимодействия СССР и Монголии.

Внешнеполитический курс СССР в отношениях с Монголией, направленный на развитие равноправных, взаимовыгодных отношений, способствовал дальнейшему укреплению доверия и взаимопонимания, созданию наилучших внешних условий для развития страны и защиты ее территориальной целостности. События 1939 г. на Халхин-Голе в восточной Монголии, когда вооруженные силы СССР и МНР одержали сокрушительную победу над войсками Японии, не только способствовали сохранению суверенитета и целостности территории Монголии, но и оказали в дальнейшем значительное влияние на результаты Второй мировой войны. 


\section{Источники}

РГАСПИ - Российский государственный архив социально-политической истории.

\section{Литература}

История Монголии 2007 - История Монголии. ХХ век. М.: Ин-т востоковедения РАН, 2007. $448 \mathrm{c}$.

Лузянин, Грайворонский $2010-$ Лузянин С. Г., Грайворонский В. В. Война на Халхин-Голе: место в мировой истории // Проблемы Дальнего Востока. 2010. № 1. С. 156-164.

Монголия в документах 2019 - Монголия в документах из архивов ФСБ России (19221936 гг.): сб. док. / науч. ред. В. В. Наумкин, отв. ред. К. В. Орлова, В. В. Грайворонский; Ин-т востоковедения РАН. М.: ИВ РАН, 2019. 528 c.

Российско-монгольское военное сотрудничество 2008 - Российско-монгольское военное сотрудничество (1911-1946): сб. док.

\section{References}

Khlevnyuk O. V. et al. (comps.) Stalin and Kaganovich: Correspondence, 1931-1936. Moscow: ROSSPEN, 2001. 798 p. (In Russ.)

Kudryavtsev I. I. et al. (comps.), Kozlov V. P. (eds.) Russian-Mongolian Military Cooperation, 1911-1946: Collected Documents. In 2 vols. Vol. 1. Moscow; Ulan-Ude: East-Siberian State Academy of Culture, 2008. 349 p. (In Russ.)

Luzyanin S. G., Graivoronsky V. V. The war of Khalkhin Gol and its place in world history. The Far Eastern Affairs. 2010. №1. Pp. 156-164. (In Russ.)

Naumkin V. V., Orlova K. V., Graivoronsky V. V. (eds.) Federal Security Service Archives: Mongolia Documented, 1922-1936. Moscow:

\section{Sources}

Russian State Archive of Socio-Political History.

в 2 ч. Ч. І. М.; Улан-Удэ: Издат.-полиграф. комплекс ФГОУ ВПО ВСГАКИ, 2008. 349 с.

Рощин 1999 - Рощиин С. К. Политическая история Монголии (1921-1940 гг.). М.: ИВ РАН, $1999.327 \mathrm{c}$.

Рощин 2005 — Рощчин C. К. Маршал Монголии Х. Чойбалсан. Штрихи биографии. М.: Институт востоковедения РАН, 2005. 160 с.

Рощин 2008 - Рощчин С. К. П. Гэндэн, монгольский национальный лидер. Штрихи биографии. М.: Институт востоковедения РАН, 2008. $160 \mathrm{c}$.

Сталин и Каганович 2001 - Сталин и Каганович. Переписка. 1931-1936 гг. / сост. О. В. Хлевнюк, Р. У Дэвис, Л. П. Кошелева, Э. А. Рис, Л. А. Роговая. М.: «Российская политическая энциклопедия» (РОССПЭН), 2001. 798 с.; ил.

Institute of Oriental Studies (RAS), 2019. 528 p. (In Russ.)

Roshchin S. K. P. Genden, a National Leader of Mongolia: Biographical Sketches. Moscow: Institute of Oriental Studies (RAS), 2008. 160 p. (In Russ.)

Roshchin S. K. Political History of Mongolia, 1921-1940. Moscow: Institute of Oriental Studies (RAS), 1999. 327 p. (In Russ.)

Roshchin S. K. The Marshal of Mongolia Kh. Choibalsan: Biographical Sketches. Moscow: Institute of Oriental Studies (RAS), 2005. 160 p. (In Russ.)

Yaskina G. S. (ed.) History of Mongolia: 20 Century. Moscow: Institute of Oriental Studies (RAS), 2007. 448 p. (In Russ.) 